\title{
WHAT REMAINS
}

\section{Dear Reader,}

The year is coming to a close and you are holding the last issue of 2014 in your hands. Once again, 52 weeks have flown by, and probably only a few of the New Year's resolutions that were made last December have actually been put into practice. Some really did manage to quit smoking, while others achieved their goal of losing a bit of weight. So maybe everyone has his little experience of success in the private sector.

But what were the business highlights of the automotive industry over this past year? What will remain when we look back on 2014? Without doubt, electric mobility has made a major step forward this year. The hype was superseded by a greater sense of reality for what is feasible and sensible. For example, 2014 saw the delivery of the first BMW i3, a groundbreaking vehicle for the industry. Less positive news in 2014, on the other hand, was the announcement from Rüsselsheim that production of the Ampera is to end in 2016.

The number 1 annoying topic of the year was, and still is, the interminable debate concerning the refrigerants R134a, R1234yf and $\mathrm{CO}_{2}$, which we reported on at length and discussed in detail in our articles and reports as well as in our online dossiers at www.springerprofessional.de and our editorials. The latest online news is that Brussels is increasing the pressure on Germany in the dispute over the refrigerant R1234yf in Mercedes air conditioning systems. The European Commission has initiated the next level of proceedings relating to the infringement of EU treaties.

The second long-running topic is the introduction of a road toll for cars in Germany. Is it going to happen or not? There are still many questions that have yet to be answered by Transport Minister Alexander Dobrindt. He presented his concept as long ago as last July. It had many critics, including the IT industry association Bitkom, which expressed its concerns about the concept in September. It said that the planned implementation was half-hearted and that the technology behind the toll collection system was not state-of-the-art.

And what was the event of the year for us in the editorial team? Without doubt, the $75^{\text {th }}$ anniversary of our sister magazine MTZ. From the perspective of ATZ - the grand old lady soon to be in the $117^{\text {th }}$ year of publication - MTZ is 41 years younger and still a youthful girl. We celebrated the anniversary with a wonderful party at "Mahle Inside", where we welcomed a large number of guests, friends and partners from the field of engines and drivetrains.

The new year is bound to be just as progressive as the old one. To paraphrase the German humorist Wilhelm Busch: One two three, in a frantic race, time is hurrying - we keep pace. I hope you will find some pleasant surprises of the ATZ relaunch in our January issue.

With kind regards,

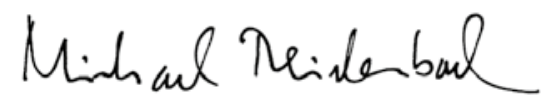

DIPL.-ING. MICHAEL REICHENBACH,

Vice-Editor in Chief

Wiesbaden, 27 October 2014

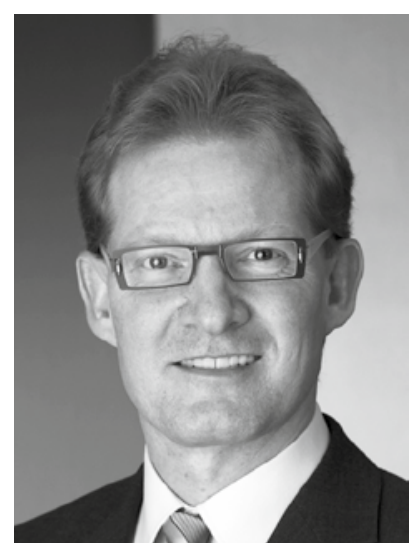

